\title{
EFFECTS OF DIETARY SODIUM MONENSIN ON THE METABOLIC AND HORMONAL PROFILES OF DAIRY GOATS DURING THE PERIPARTUM PERIOD
}

\section{AVALIAÇÃO DO USO DA MONENSINA SÓDICA NO PERFIL METABÓLICO E HORMONAL EM CABRAS LEITEIRAS NO PERIPARTO}

\author{
Cleyber José Trindade de Fátima ${ }^{{ }^{*}}$ \\ Carla Lopes de Mendonça ${ }^{1}$ \\ Adony Querubino de Andrade Neto ${ }^{1}$ \\ Adalberto Freire do Nascimento Júnior ${ }^{2}$ \\ Sergio Peres Ramos da Silva² \\ José Augusto Bastos Afonso ${ }^{1}$ \\ ${ }^{1}$ Federal Rural University of Pernambuco, Recife, PE, Brazil. \\ 2 Pernambuco State University, Recife, Brazil. \\ "Corresponding author - cleybertrindade@gmail.com
}

\begin{abstract}
This study aimed to investigate the energetic and hormonal profiles of dairy goats fed diets supplemented with monensin during the peripartum period. Eleven pregnant Saanen goats were subdivided into two random groups, a control group (GC) and the monensin group (MG). The MG group received $40 \mathrm{mg}$ sodium monensin per animal per day for 15 days before partum and throughout the subsequent experimental period. Clinical observations and sample collection were performed at 30, 15, and 7 days before birth; on the day of partum; and at 5, 15, and 30 days after birth. The following biochemical and hormonal profile variables analyzed were: cholesterol, triglycerides, glucose, fructosamine, non-esterified fatty acids (NEFAs) and $\beta$-hydroxybutyrate (BHB), cortisol, and insulin. The ruminal fluid $\mathrm{pH}$, chloride content, and volatile fatty acids were also measured. Statistical analysis of the data was performed using repeated measures ANOVA $(p<0.05)$ and Pearson's correlation. At partum, the MG group had lower values of NEFAs and lower acetate/propionate ratio. MG had higher triglycerides during the entire experiment period. The administration of monensin generated benefits in terms of energy parameters, improving the metabolic status of the dairy goats during peripartum.
\end{abstract}

Keywords: Volatile fatty acids, ionophores, energy profile, hormonal profile, lactation.

\section{Resumo}

Objetivou-se estudar o perfil energético e hormonal em cabras leiteiras suplementadas com monensina sódica durante o periparto. Utilizou-se onze cabras Saanen gestantes subdivididas em dois grupos de forma aleatória; um grupo controle (GC) e o grupo monensina (GM); o GM recebeu na dieta $40 \mathrm{mg}$ por animal/dia de monensina sódica. As coletas das amostras foram efetuadas nos períodos de $-30,-15$, e -7 dias do parto, no dia do parto, $+5,+15$ e +30 dias do parto. As variáveis 
bioquímicas e hormonais analisadas foram: colesterol, triglicerídeos, glicose, frutosamina, ácidos graxos não esterificados (AGNE) e $\beta$-hidroxibutirato (BHB), cortisol e insulina. Também foram mensurados no fluido ruminal o $\mathrm{pH}$, o teor de cloretos e os ácidos graxos voláteis. A análise estatística dos dados foi realizada pelo método da ANOVA $(p<0,05)$ e foi realizado estudo de correlação de Pearson. No momento do parto, o GM apresentou em relação ao GC índices mais baixos de AGNEs e menor relação acético/propiônico $(\mathrm{p}<0,05)$. Em relação aos triglicerídeos, o GM apresentou valores superiores ao GC $(p<0,008)$ ao longo do experimento. A administração de monensina gerou benefícios nos parâmetros energéticos, melhorando o status metabólico de cabras leiteiras no periparto.

Palavras Chave: Ácidos graxos voláteis, ionóforos, perfil energético, perfil hormonal, lactação.

Received on: February 9, 2018.

Accepted on: May 28, 2018

\section{Introduction}

The transition period in goats includes three weeks before and after calving and is considered critical in view of the intense metabolic changes and adaptations to a new physiological state. In this period, losses may occur under conditions of negative energy balance between nutrient demand and adequate supply, resulting from the high nutritional requirement caused by the rapid development of the fetuses and the mammary gland, in addition to a reduced food intake during this period. In some situations, these complicating factors lead to the occurrence of metabolic disorders, such as toxemia of $\operatorname{pregnancy}^{(1)}$.

One possibility to minimize the impact of a negative energy balance during this period relies on the addition of ionophore antibiotics to the diet. These include monensin sodium, which is a carboxylic polyether resulting from the fermentation of Streptomyces cinnamonensis. Monensin sodium has been extensively used to control coccidiosis and improve feed efficiency in ruminants. As an ionophore, it modifies the flow of monovalent ions through the cell membrane, thus altering the profile of the microbial population in the rumen. It selectively inhibits Gram-positive bacteria while preserving Gram-negative pathogens, because of their different cell wall structures. Some effects of this antibiotic that change the pattern of ruminal fermentation have previously been described. These include increased production of propionate and a reduced ratio of acetate/propionate. It also decreases the concentration of methane in the rumen environment. The consequences of these changes directly influence the metabolic pathway of gluconeogenesis ${ }^{(2,3)}$.

There is evidence that using monensin sodium in dairy cows reduces the concentrations of $\beta$ hydroxybutyrate (BHBA) and non-esterified fatty acids (AGNE), while raising the concentration of blood glucose. These changes follow a logical pattern of improving and coordinating energy metabolism, providing a beneficial effect to dairy cows in the transition period, in particular. In addition, it was observed that these alterations lead to a more positive adaptive response during the transitional period and lactation ${ }^{(4)}$. Monensin supplementation in pregnant sheep during the transition period has shown positive effects on energy indicators and milk components ${ }^{(5,6)}$.

However, there are few studies discussing the use of monensin sodium during peripartum as an 
alternative strategy to prevent metabolic disorders in dairy goats. Most studies with ionophores in goats involved limited use of ionophores as a coccidiostat while breeding, and to prevent rumen $\operatorname{acidosis}^{(7,8,9,10)}$. Therefore, the aim of this study was to investigate the influence of monensin on the metabolic profile, and, consequently, on energy and hormonal metabolism in Saanen dairy goats.

\section{Materials and Methods}

The project was carried out at the Bovine Clinic (CBG), Campus-Garanhuns, at the Federal Rural University of Pernambuco. Eleven multiparous pregnant Saanen goats were used for this study. These presented an average weight of $50 \mathrm{~kg}$. The goats were clinically healthy and previously dewormed with Levamisole and vaccinated against clostridiosis.

During the experiment, the goats were kept in a sheep-fold and were fed with a concentrated balanced diet (400g/animal/day), divided into two daily rations: bulk food, composed of elephant grass (Pennisetum purpureum) and tifton (Cynodum sp); mineral salt (Ovinofós $\left.{ }^{\circledR}\right)$; and water ad libitum. This diet was determined to satisfy the nutritional requirements of dairy goats during this period (NRSR 2007). The animals were randomly divided: five in the control group (CG) and six in the monensin-treated group (MG). The CG received the aforementioned diet, while MG received the same diet supplemented with $40 \mathrm{mg} /$ animal/day of monensin sodium, present in the concentrate and mineral salt (Max ovinos reprodução ${ }^{\circledR}$ and Ovinofós ${ }^{\circledR}$ salt with monensine). The administration of these diets started two weeks before sample collection, to allow the animals to adapt. The goats and pregnancies were monitored by clinical examination, accompanied by ultrasound. The clinical observations during the experiment and sample collections for laboratory tests were carried out in the morning, before the first daily ration, 30, 15, and 7 days before calving (DBC); on the calving day; and on post-partum day 5, 15, and 30 (PPD).

Blood samples were collected by jugular vein puncture into silicone-coated Vacutainer ${ }^{\circledR}$ tubes with anticoagulant (sodium fluoride/oxalate) to obtain plasma samples, which were used to determine glucose and total plasma protein (TPP). The serum obtained from tubes without anticoagulant was employed in the biochemical and hormonal analyses. Serum and plasma samples were aliquoted into Eppendorf $^{\circledR}$ tubes and stored at a temperature of $-80{ }^{\circ} \mathrm{C}$ (Ultralow freezer NuAire Inc., 2100 Fernbrook Lane N. Plymouth, Mn 55447, USA).

The biochemical variables analyzed were cholesterol, triglyceride, glucose, fructosamine, nonesterified fatty acids (NEFA), and $\beta$ - hydroxybutyrate (BHB) levels. All biochemical indicators were analyzed using commercial Labtest ${ }^{\circledR}$ kits and RANBUT - Randox Laboratories (BHB and NEFA). Cortisol and insulin were analyzed by the electrochemiluminescence method in serum samples, using the commercial kit (Cortisol and Insulin CObas, Roche ${ }^{\circledR}$ ). Urine samples were obtained by animal spontaneous urination and were immediately investigated for the presence of ketone bodies using urinalysis reagent strips $\left(\right.$ Labtest $\left.^{\circledR}\right)$.

Approximately $300 \mathrm{~mL}$ of rumen fluid was collected from each animal 15 and $7 \mathrm{DBC}$, on the calving day, and 5 and 15 days PPD, between 2 and 4 hours after the morning feeding. The fluid was obtained through an oro-gastric probe with a metal nozzle, which was adapted to a suction pump in order to aspirate the content into an individual glass tube previously heated to $39{ }^{\circ} \mathrm{C}$. Subsequently, these 
ruminal fluid samples were stored into identified thermal bottles, which were previously heated at 39 ${ }^{\circ} \mathrm{C}$, until processing in the laboratory, that is, up to $15 \mathrm{~min}$ after sample collection.

The concentrations of volatile fatty acids (VFAs) (acetic, propionic, and butyric) were determined by gas chromatography ${ }^{(11)}$. In this analysis, the ruminal fluid samples, previously filtered through five layers of gauze and centrifuged (3000 $\times \mathrm{g}$ for $15 \mathrm{~min}$ ), were placed in vial tubes, diluted with $6 \%$ metaphosphoric acid in a ratio of $1: 1$, and stored in an ultrafreezer at $-80{ }^{\circ} \mathrm{C}$. The chromatography calibration curve (Agilent CG-MS®) was based on a concentrated standard solution from which dilutions were made to generate five standards. For acetic acid, the values of the solutions varied from 40.7840 to $2.549 \mathrm{~g} / \mathrm{L}$; for propionic acid, it varied from 15.3012 to $0.9563 \mathrm{~g} / \mathrm{L}$; and for butyric acid, the concentration ranged between 10.1762 and $0.6360 \mathrm{~g} / \mathrm{L}$. The Thermo Scientific gas chromatograph, Trace GC Ultra model (equipped with a flame ionization detector and PTV type injector, with a $30 \mathrm{~m}$ long capillary Megabore carbowax BP20 column (SGE brand), a $0.5 \mu \mathrm{m}$ film, and an external diameter of $0.53 \mathrm{~mm}$ ) was used. The oven (where the column was located) and injector were at an isothermal temperature of $200^{\circ} \mathrm{C}$, with $1: 15$ split, with a mobile phase flow of 1.5 $\mathrm{mL} / \mathrm{min}$. In each chromatographic run, a sample volume of $1 \mu \mathrm{L}$ was injected. The data were obtained using the Chromquest 5.0 software.

The $\mathrm{pH}$ (Corning 30) and the fluid chloride content were also analyzed ${ }^{(12)}$.

The obtained values were analyzed statistically, during seven experimental periods, in which the study variables were submitted to repeated measures analysis of variance, for analyzing the group and time effects, at the 5\% significance level. The contrasts between the group means were found out using Tukey's post hoc tests. Pearson's correlation analysis was performed to assess the degree of relationship between variable pairs at the $5 \%$ level of probability.

The project was approved by the Animal Use Ethical Committee (CEUA) of the Federal Rural University of Pernambuco, under permission number 020/2015 CEPE/UFRPE.

\section{Results and Discussion}

All goats had eutocic calving, with on average 1.45 calves/goat. The body score of the goats at the beginning of this study varied from 3.0 to 3.5; at the end, their body score was maintained at 3.0. The goats showed negative results for the presence of ketone bodies in urine and remained healthy throughout the study period.

There were no significant differences between the CG and MG groups in terms of the VFAs analyzed (acetic, propionic, and butyric) $(\mathrm{p}>0,05)$. However, the $\mathrm{CG}$ had higher acetic and butyric acid indexes were than in the MG group, while propionic acid concentrations were higher in the group that received the ionophore (Figure 1). When analyzing the acetic/propionic (A/P) acid ratio, a difference $(\mathrm{p}=0.002)$ was observed between $\mathrm{MG}$ and $\mathrm{CG}$, which had ratios of $2.28 \mathrm{~g} / \mathrm{L}$ and $2.96 \mathrm{~g} / \mathrm{L}$, respectively (Figure 2). This change in the VFAs proportion was also observed by Brown and Hogue $^{(13)}$, Mousa ${ }^{(14)}$, and Aderinboye et al. ${ }^{(15)}$ in dairy goats and young and confined male goats receiving monensin in diets at concentrations known to improve feed efficiency. Analyzing the effect of this ionophore on dairy cows during the transition period, Markantonatos et al. ${ }^{(16)}$ observed that a reduction in the acetate/propionate ratio occurred because of the decreased production of acetate. 
These findings might be explained by the action of this ionophore, which modifies the bacterial population in the rumen and selectively inhibits Gram-positive bacteria while preserving the Gramnegative bacteria. This leads to a higher production of propionate and reduction in the acetate / propionate ratio $^{(2,3,17)}$. This difference in ruminal bacterial population in the $\mathrm{MG}$ affected the behavior of metabolites, dictating the energy and hormonal profile, as can be verified in the strong, moderate, and strong negative relationships found between variables (Figure 9).

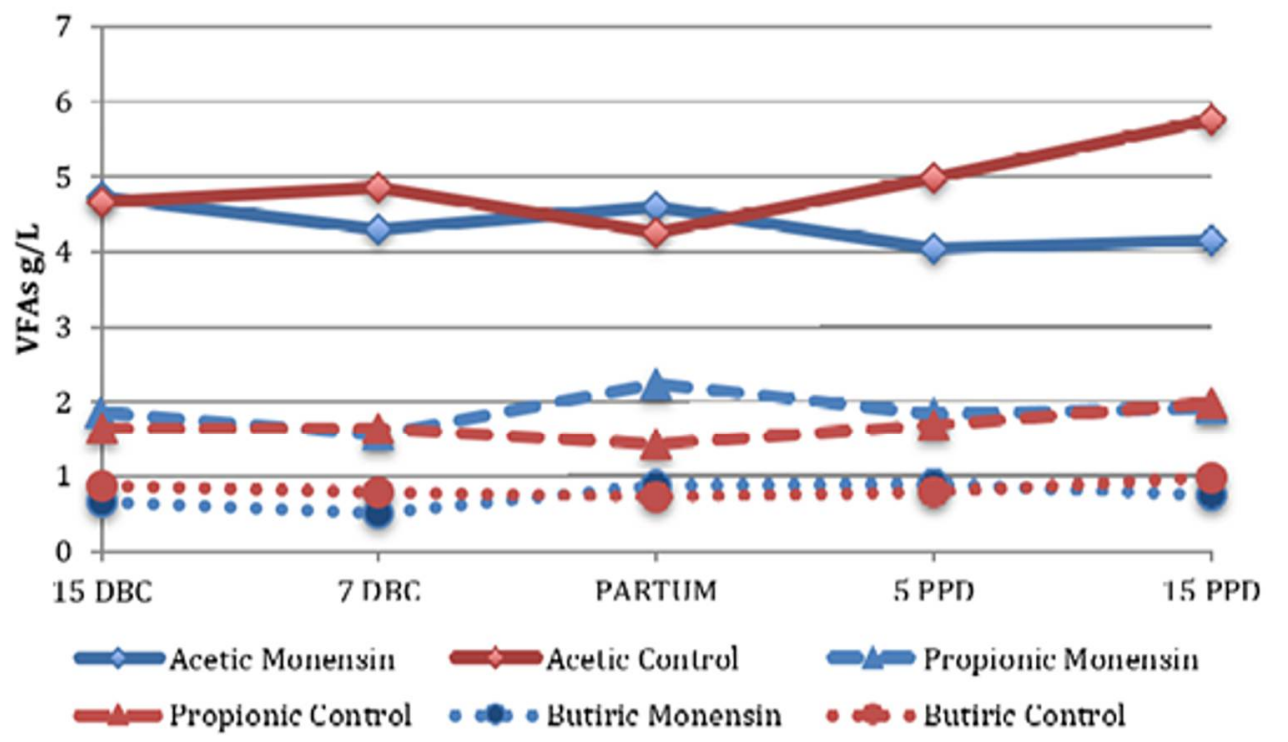

Figure 1. Average values of volatile latly acids $(\mathrm{g} / \mathrm{L})$ in goats supplemented with monensin and in control goats during peripartum.

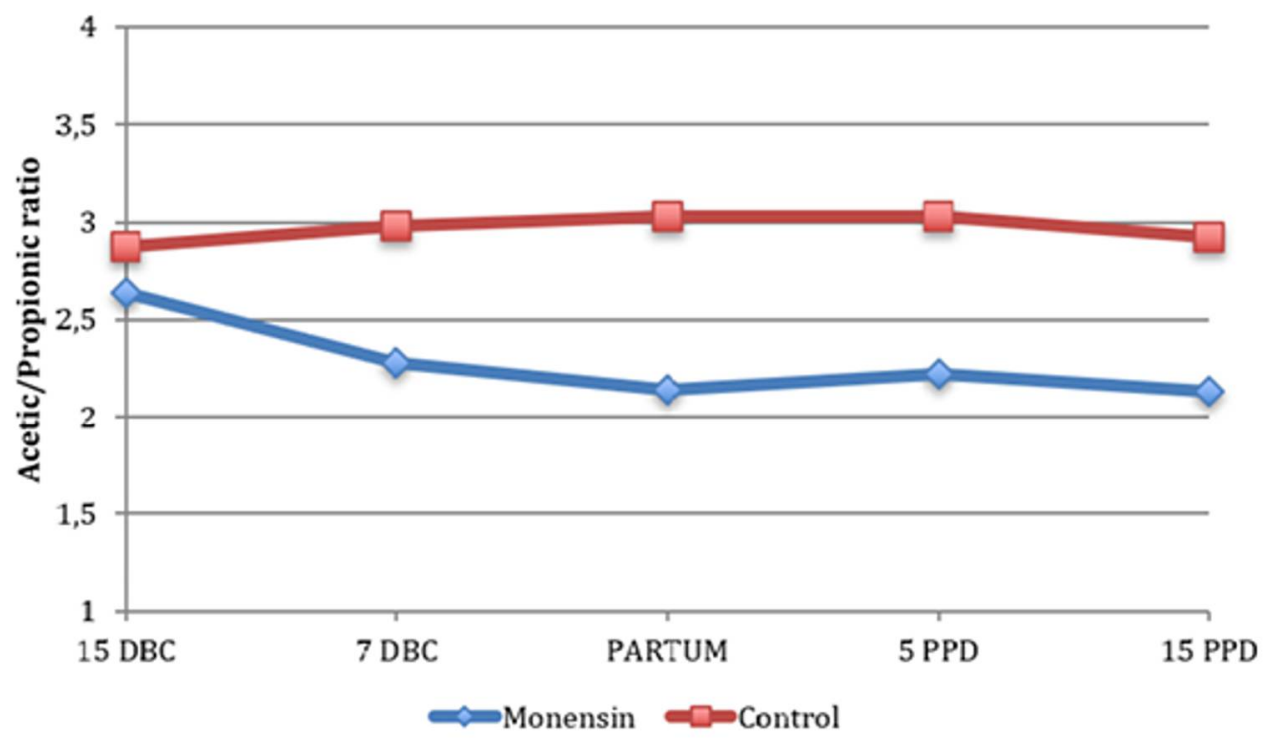

Figure 2. Average values of acetic/propionic acids ratio $(\mathrm{g} / \mathrm{L})$ in goats supplemented with monensin and in controls goat during peripartum.

The $\mathrm{pH}$ of the rumen fluid in the control group appeared to be statistically higher at calving than in the other sampling periods $(p=0.02)$. However, there were no differences between the groups $(p>0.05)$ (Figure 3$)$. Brown and Hogue ${ }^{(13)}$ and Aderinboye et al. ${ }^{(15)}$ working with goats, Markantonatos et al. ${ }^{(16)}$ working with dairy cows, and Lima et al. ${ }^{(5)}$ working with sheep also found no significant variations in $\mathrm{pH}$ between groups 
of animals receiving monensin supplementation or the control animals. This $\mathrm{pH}$ stability is probably attributed to the steady concentration of volatile fatty acids in the rumen during the experiment.

Analyzing the concentration of chloride ions in the rumen content, although the values were observed to have decreased overtime, no significant differences were observed between the different sampling periods or between the groups ( $\mathrm{p}>0.05$ ) (Figure 3). The values obtained, $30.94 \mathrm{mmol} / \mathrm{L}$ in $\mathrm{MG}$ and $33.38 \mathrm{mmol} / \mathrm{L}$ in the CG, are slightly above the reference range for the species $(21.0 \pm 2.2 \mathrm{mmol} / \mathrm{L})^{(5)}$. The importance of this data is precisely the difference between the parameters found in the international literature and the concentrations of this element in this study, that is, in healthy dairy goats living according to Brazilian environmental, climate, and food patterns.

Analyzing the non-esterified fatty acids (NEFAs), we observed that these presented an effect of time in the two groups $(\mathrm{CG} \mathrm{p}=0.001$ and $\mathrm{MG} \mathrm{p}=0.04)$, with an increase in the values at calving to $1.53 \pm 0.28 \mathrm{mmol} / \mathrm{L}$ and $0.77 \pm 0.33 \mathrm{mmol} / \mathrm{L}$, respectively. When comparing the groups, there was a statistical difference at calving ( $\mathrm{p}=0.003)$, since the CG group presented higher average values of NEFAs than the MG group (Figure 4). These changes in the concentrations of NEFAs reflect the rate of mobilization from fat deposits owing to a negative energy balance. This is more significant in CG, where it occurred in the last days of gestation and resulted from a gradual reduction in dry matter intake ${ }^{(10)}$. During this period, there was an associated increase in plasma levels of lipolytic hormones (cortisol and glucagon), which also contributed to the increase in the levels of the NEFAs ${ }^{(18)}$. These factors explain the higher level of NEFAs at calving observed in both groups in this study. However, Rios et al. ${ }^{(19)}$, working with dairy goats, and Lima et al. ${ }^{(5)}$, in a study on monensin supplementation to the diet of sheep, observed an increase in the NEFAs in the initial lactation period and explained this result in terms of the high energy requirement for milk production during this period.

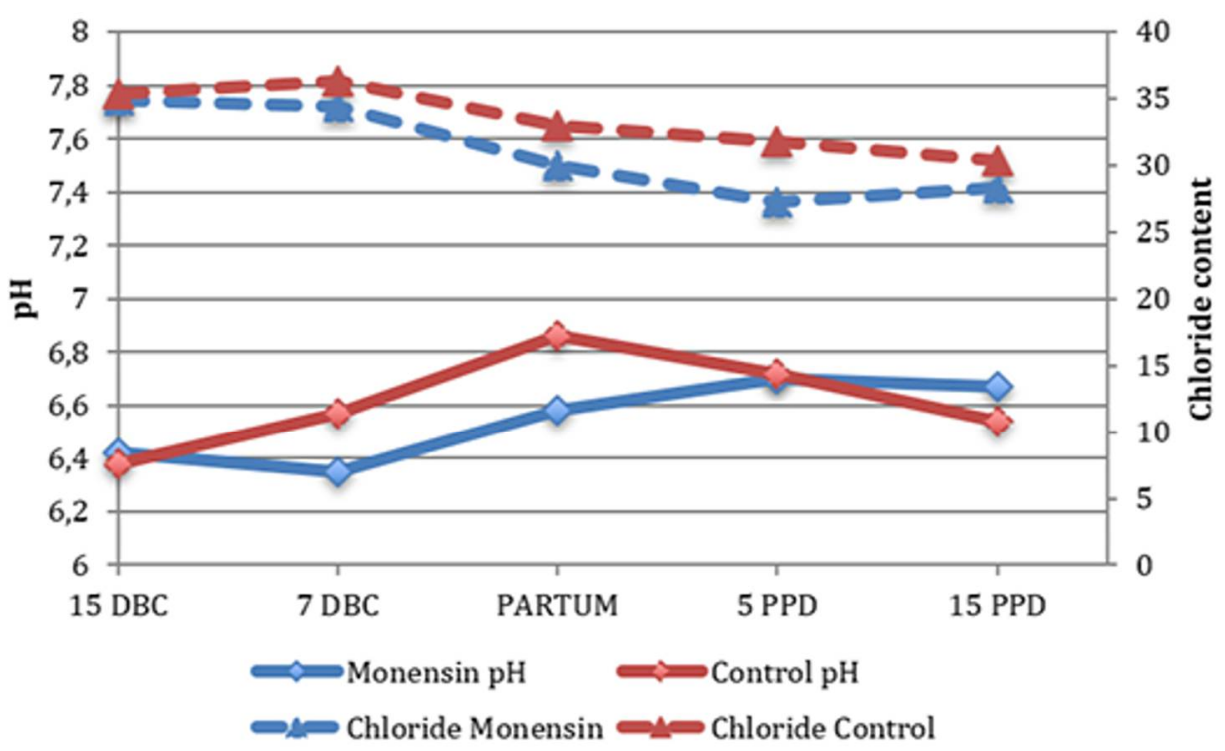

Figure 3. Average values of $\mathrm{pH}$ and chloride content of rumen fluid in goats supplemented with monensin and in control goats during peripartum.

As for the differences found between the groups ( $\mathrm{CG}$ and $\mathrm{MG})$ at calving, these may be explained by the action of monensin in the ruminal environment, which influenced the proportional increase in propionate supply in animals that received this ionophore. As a result, these animals presented a lower degree of negative energy balance and consequently less fat mobilization ${ }^{(4)}$. This factor explains the result wherein the MG presented a lower NEFAs index than the CG, as shown by the strong and negative relation with $\mathrm{A} / \mathrm{P}(\mathrm{r}=-0.87)$ (Figure 2$)$. In turn, Taghipoor et al. ${ }^{(20)}$, using monensin in 
sheep, obtained similar effects on the decrease of NEFAs during peripartum. However, Sadjadian et al. ${ }^{(10)}$, who also worked with dairy goats, and Lima et al. ${ }^{(5)}$, working with sheep, did not find relevant effects on the NEFAs values in the peripartum period when using monensin.

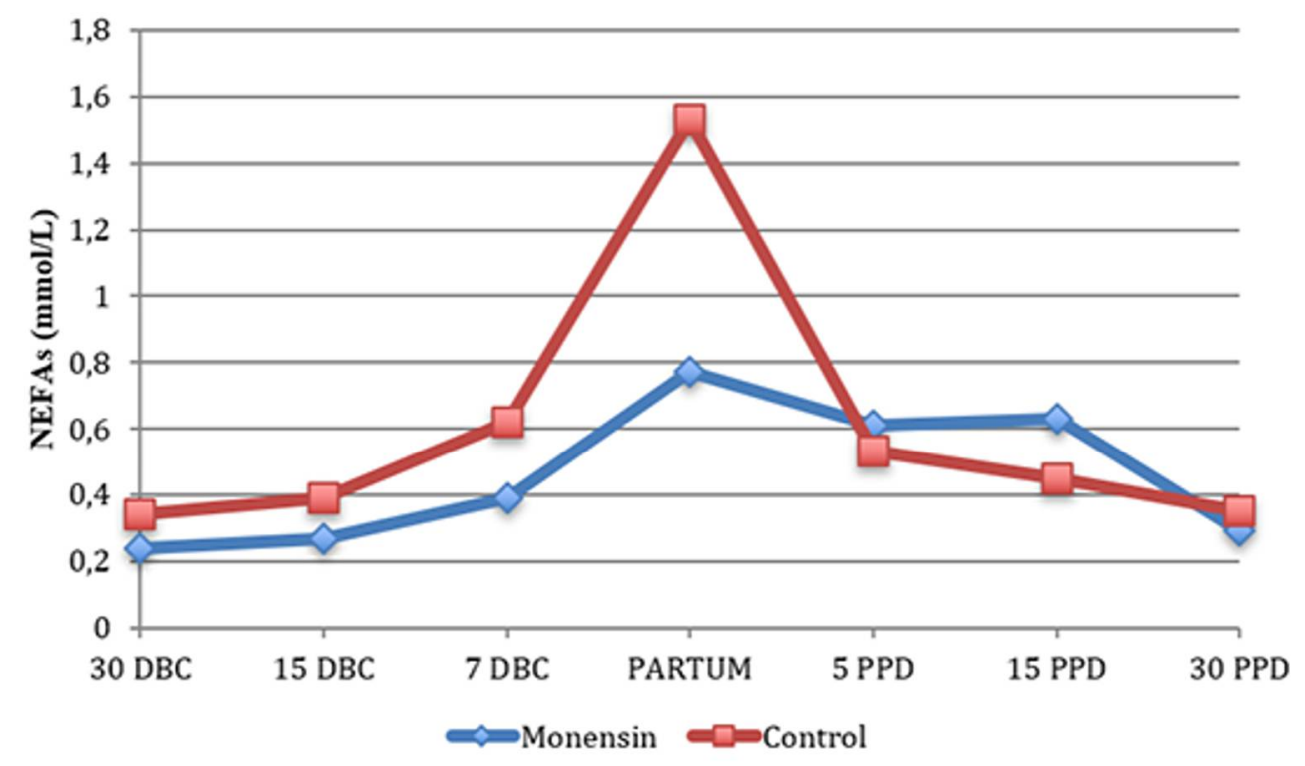

Figure 4. Average level of Non-Esterified Fatty Acids $(\mathrm{mmol} / \mathrm{L})$ in goats supplemented with monensin and in control goats during peripartum.

The values obtained for $\beta$-hydroxybutyrate (BHB) did not differ statistically between the different sampling periods analyzed $(p>0.05)$ in the two groups, despite the fact there was a higher birth rate in the $\mathrm{CG}(0.72 \pm 0.72 \mathrm{mmol} / \mathrm{L})$. The comparison between the groups also did not show statistical difference ( $p>0.05$ ), although the concentrations of BHB in MG were lower in almost all periods considered (Figure 5). Similar results were reported by Sadjadian et al. ${ }^{(10)}$ who, when working with Saanen goats, found lower BHB values during post-partum in the group receiving monensin than in the control group. However, other studies in sheep report the beneficial effects of monensin on the negative energy balance in the transition period in order to decrease the concentration of BHB during peripartum ${ }^{(6,10,20)}$. In the present study, the differences found were probably not statistically significant since healthy goats were used in both groups. Nevertheless, this result is consistent with the mechanism of action of monensin, in increasing the production of propionate and reducing the concentration of butyrate in the rumen. Under this condition, a gluconeogenic benefit has been observed, which results in a greater supply of glucose with lower production of ketone bodies $^{(21)}$.

A significant increase in the level of glucose $(\mathrm{p}=0.001)$ was observed at calving in both groups (MG 152.25 $\pm 61.64 \mathrm{mg} / \mathrm{dL}, \mathrm{CG} 156.44 \pm 34.66 \mathrm{mg} / \mathrm{dL}$ ). The glycemic profile was higher in MG during almost all periods analyzed; however, a statistical difference $(\mathrm{p}=0.03)$ was only observed 15 days after partum (MG $56.2 \pm 4.48 \mathrm{mg} / \mathrm{dL}$ and CG $50.1 \pm 2.97 \mathrm{mg} / \mathrm{dL}$ ) (Figure 6). Experiments with dairy goats in the transition and lactation period have shown that the highest concentration of glucose occurs at calving, as a result of the gluconeogenesis caused by hormonal changes and is influenced by cortisol ${ }^{(18,22)}$. It is known that dietary glucose has little effect on glycemia due to homeostatic mechanisms, mainly hormones such as insulin and glucagon ${ }^{(23)}$. However, with the increase of the propionate molar ratio in monensin-supplemented diets, there is increased gluconeogenesis that influences the glycemia of animals under the effect of this ionophore $^{(21)}$. This condition explains the higher increase in glucose levels in the monensin group during 
almost all periods, with a more prominent difference at 15 days after calving. This was highlighted by the strong positive relation $(r=0.85)$ between these variables (Figure 9). The findings regarding the benefit of monensin on blood glucose levels are variable. Austin and Wilde ${ }^{(6)}$ and Mousa ${ }^{(14)}$ also observed increased blood glucose in the group receiving the ionophore during peripartum. However, Taghipoor et al. ${ }^{(20)}$, Sadjadian et al. ${ }^{(10)}$, and Lima et al. ${ }^{(5)}$ found no significant changes in blood glucose in animals supplemented with the antibiotic in this period.

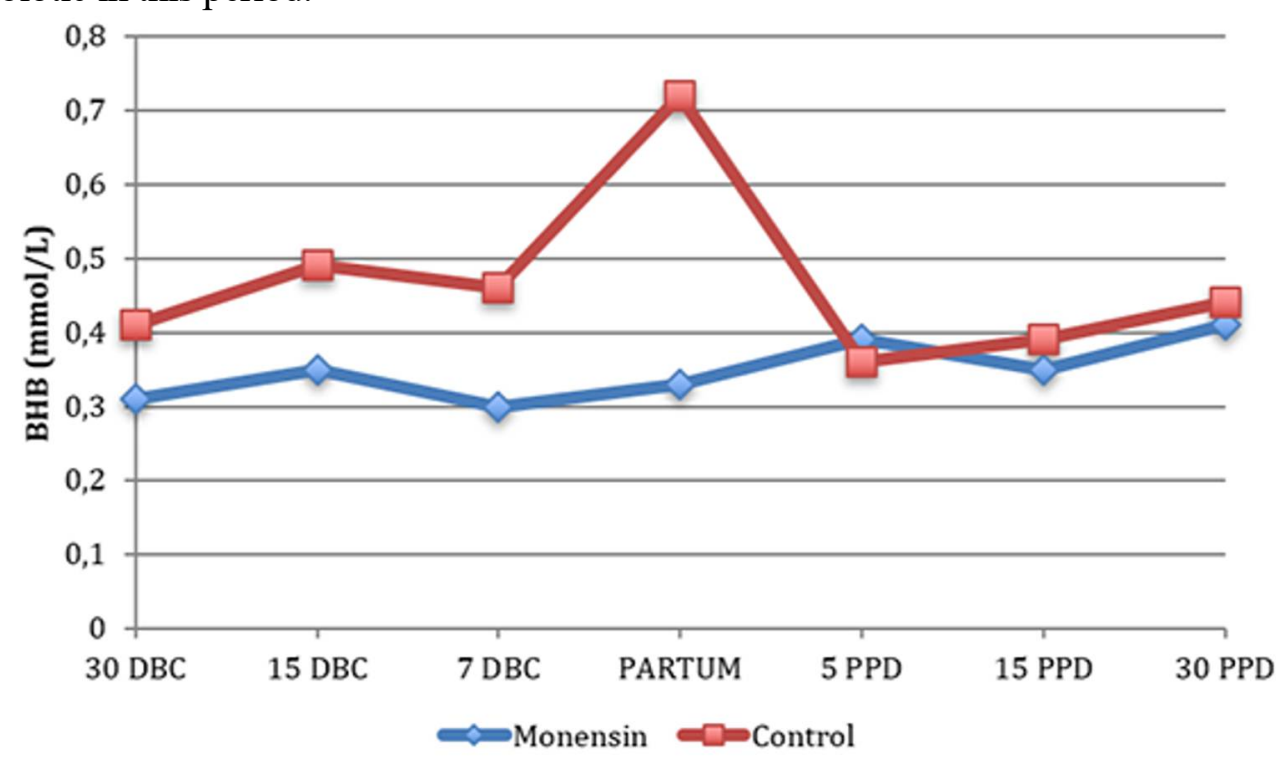

Figure 5. Average values of $\beta$-hydroxybutyrate $(\mathrm{mmol} / \mathrm{L})$ in goats supplemented with monensin and in control goats during peripartum.

The concentrations observed for fructosamine revealed a statistical difference between periods only in the MG $(\mathrm{p}=$ 0.04), where 15 DPP and 30 DPP showed higher values (Figure 6). Similarly, Filipovic et al. ${ }^{(24)}$ and Lima et al. ${ }^{(5)}$, when analyzing fructosamine during sheep peripartum, observed an increase in this variable starting from 20 days after calving. However, when the groups in our study were compared with each other, there were no statistical differences $(\mathrm{p}>0.05)$. This result differs from that found by Lima et al. ${ }^{(5)}$ where Santa Inês sheep supplemented with monensin presented higher values for this variable. In the current study, the fructosamine curve did not follow the increase in blood glucose at calving, since transitional changes in blood glucose levels do not affect fructosamine concentration ${ }^{(25)}$. As there was no notable ketone or energy deficit, no differences were observed in the concentrations of fructosamine between the two groups. Nevertheless, the inclusion of this variable in this work is justified by its increasing use in studies on metabolic profiles owing to the lower variability of this molecule over time, since it depends on the average glucose concentration over the previous two weeks and the concentration of proteins such as albumin ${ }^{(24,26)}$.

Cholesterol showed no time or group effect $(p>0.05)$ (Figure 7). These findings were also reported by Taghipoor et al. ${ }^{(20)}$, Sadjadian et al..$^{(10)}$, and Lima et al..$^{(5)}$, using monensin in the diet. Some studies in goats and dairy cows show a decrease in prepartum cholesterol levels due to its requirements for fetal growth and steroid hormone synthesis. In turn, in the postpartum period, concentrations of cholesterol in dairy animals reach their maximum, as there is a gradual increase due to glucagon influence and the synthesis of plasma lipoproteins ${ }^{(22,27,28,29)}$. In the present study, this increase was not verified, possibly because of the variability of factors such as milk production, lactation period, and the diet provided. 


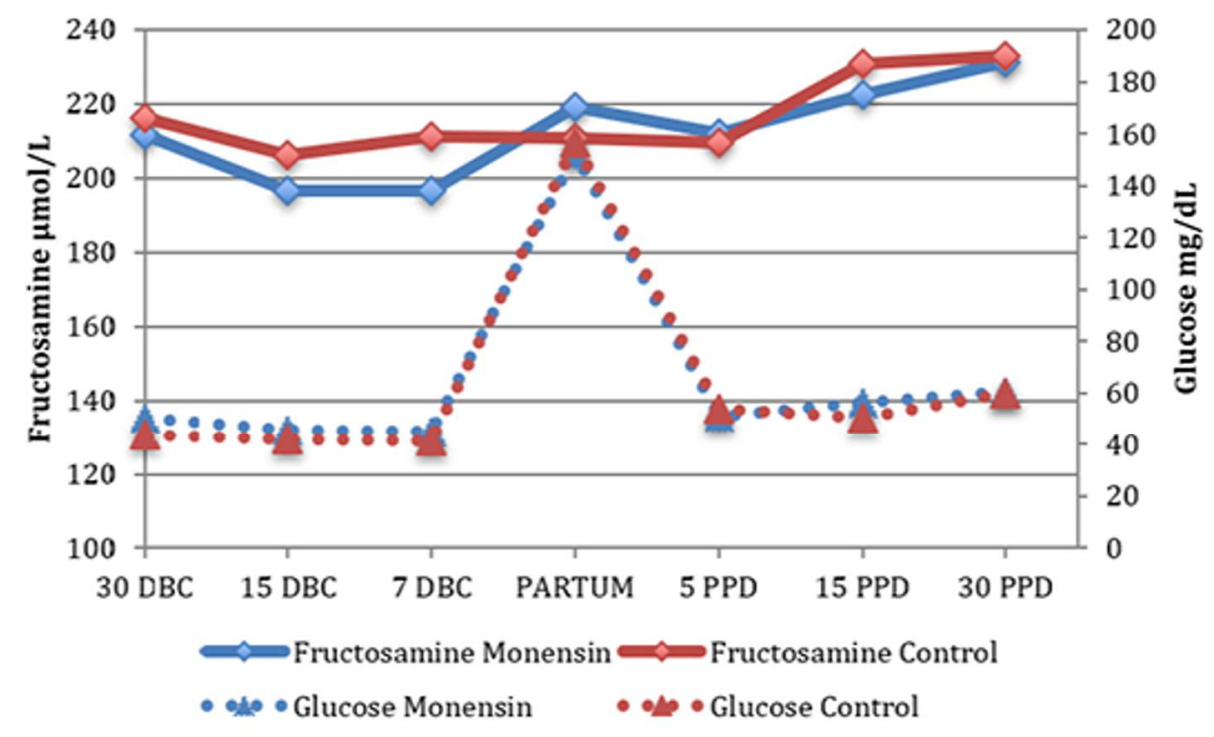

Figure 6. Average values of glucose $(\mathrm{mg} / \mathrm{dL})$ and fructosamine $(\mu \mathrm{mol} / \mathrm{L})$ of goats supplemented with monensin and in control goat group during peripartum.

Contrarily, when analyzing triglycerides, statistical differences were found between periods in both groups $(\mathrm{p}=0.001)$, where prepartum values were higher (Figure 7). These findings corroborate the work of Mundim et al ${ }^{(30)}$, Sadjadian et al. ${ }^{(22)}$, and Manat et al. ${ }^{(18)}$ in dairy goats and the study by Lima et al. ${ }^{(5)}$ in sheep, which also noted a reduction in triglyceride levels starting at calving. This reduction reflects the increased production of milk during lactation, since it is known that about two-thirds of circulating triglycerides are lipid precursors used in the synthesis of milk fat ${ }^{(30,31)}$. When the general average was compared between groups, a difference was observed $(p<0.008)$, where the monensin group $(35.65 \mathrm{~g} / \mathrm{dL})$ presented higher values than did the control group $(17.57 \mathrm{~g} / \mathrm{dL})$. These findings differ from those found by Taghipoor et al. ${ }^{(20)}$, Sadjadian et al. ${ }^{(10)}$, and Lima et al. ${ }^{(5)}$, who did not find differences when using monensin in goats and sheep diets. However, the reduction in the values of this variable was more significant in the MG than in the CG during the different periods. This finding was attributed to reduced fat deposition in the liver, caused by a lower concentration of NEFAs in prepartum, supporting the hypothesis that monensin inhibits the accumulation of triglycerides in the liver ${ }^{(29)}$.

When analyzing the time effect of insulin between groups, a significant reduction $(p=0.02)$ in the concentration of this variable was observed at calving $(1.06 \mu \mathrm{U} / \mathrm{mL})$. Subsequently, the values tended to rise, but did not return to prepartum levels. The reduction of this hormone in this period can be explained by the creation of a metabolic environment in which peripheral tissues are resistant to insulin, which minimizes their use of glucose, thereby optimizing glucose uptake by the fetus and annexed structures ${ }^{(32,33)}$. However, it should be pointed out that these data were not found in the studies by Araújo el al. ${ }^{(34)}$ and Lima et al. ${ }^{(5)}$ in sheep, in which insulin rates in this period were higher and justified by the higher concentration of glucose during this period. In the comparison between groups, there was no statistical difference $(\mathrm{p}>0.05)$, although in prepartum and calving MG presented higher levels of this hormone (Figure 8). This finding disagrees with those reported by Brown and Hogue ${ }^{(13)}$ in dairy goats and by Lima et al. ${ }^{(5)}$ in sheep receiving this ionophore. These authors explain the higher levels of insulin in animals that were supplemented with monensin by the higher production of propionic acid in the rumen, enhancing glycogenesis and consequently insulin demand. Although differences between groups were not observed in the present study, we found a moderate positive association in the $\mathrm{MG}(\mathrm{r}=0.30)$ between this hormone and the $\mathrm{A} / \mathrm{P}$ ratio, thus counteracting the moderate negative result found for the same association in the $\mathrm{CG}(\mathrm{r}=-0.40)$ (Figure 9). 


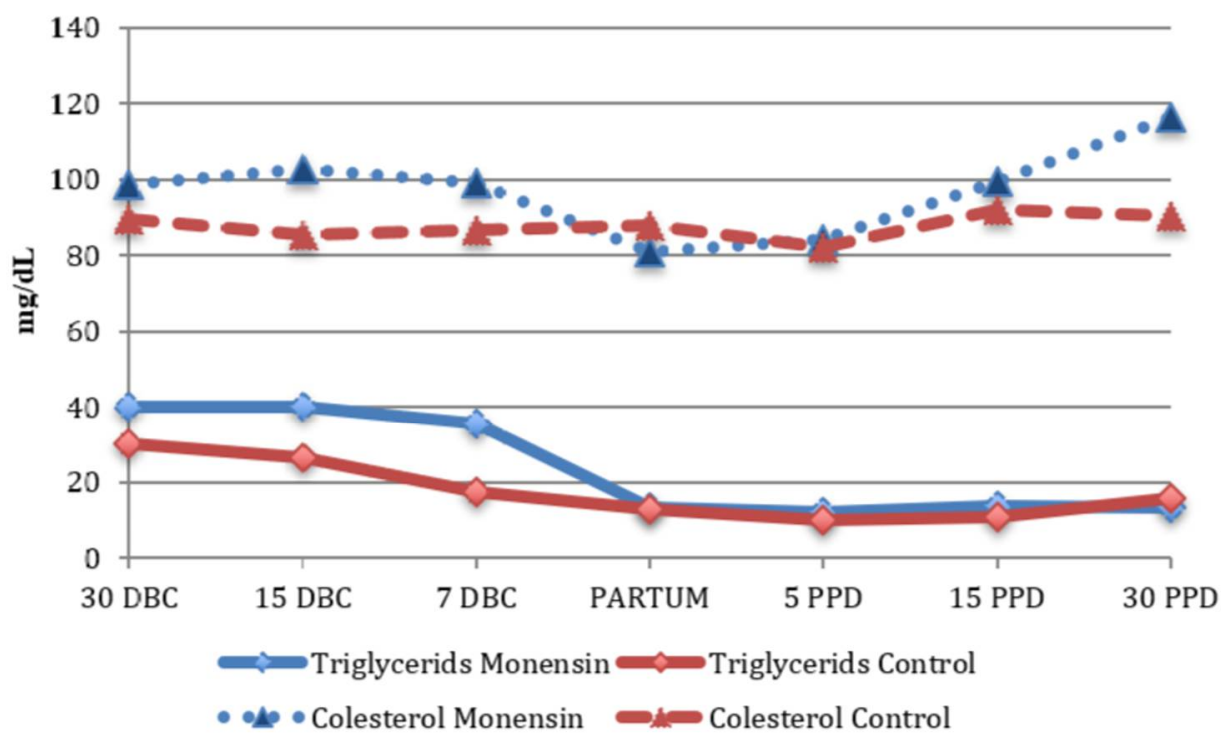

Figure 7. Average values of cholesterol and triglycerides $(\mathrm{mg} / \mathrm{dL})$ in goats supplemented with monensin and in goat controls during peripartum.

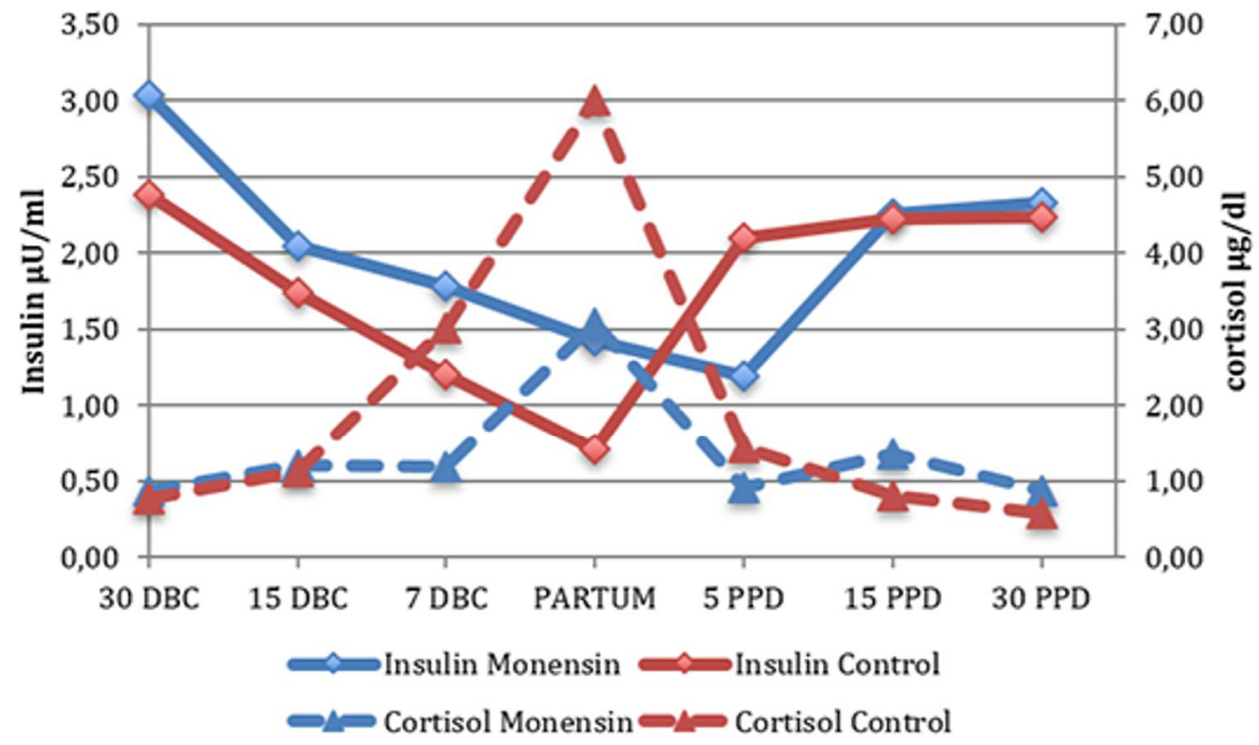

Figure 8. Average values of insulin $(\mu \mathrm{U} / \mathrm{mL})$ and cortisol $(\mu \mathrm{g} / \mathrm{dL})$ in goats supplemented with monensin and in control goats during peripartum.

As for cortisol, there was a time effect in both groups $(p=0.001)$, since the highest concentrations were observed at calving, $3.09 \pm 1.43 \mu \mathrm{g} / \mathrm{dL}$ in $\mathrm{MG}$ and $6.0 \pm 3.04 \mu \mathrm{g} / \mathrm{dL}$ in the CG. However, when comparing the groups, there were no statistical differences $(\mathrm{p}>0.05)$ (Figure 8$)$. Similar results were reported by Lima et al. ${ }^{(5)}$ in sheep receiving monensin during this period. It is known that cortisol is the main endogenous goat corticoid. It is considered to be a stress indicator and has a stimulatory effect on neoglygenesis. In stress situations, such as calving, there is an increase in blood glucose due to the action of this hormone, which in this context activates mechanisms of peripheral resistance to insulin, to prioritize energy allocation to vital organs ${ }^{(35)}$. A similar situation occurred in the present study, where an increased level of cortisol and blood glucose was observed at calving.

In analyzing the correlation coefficients with biological relevance for the main indicators studied, we found that the relationship between $\mathrm{A} / \mathrm{P}$ and insulin was moderate and positive $(\mathrm{r}=0.30)$ in the $\mathrm{MG}$ and moderate and negative in the CG $(r=-40)$ and the relationship between $\mathrm{A} / \mathrm{P}$ and NEFAs was strong and negative $(r=-0.87)$ in the MG, while in $\mathrm{CG}$, it was strong and positive $(\mathrm{r}=0.62)$. The relationship between propionic acid and plasma glucose was strong 
and positive $(\mathrm{r}=0.85)$ in $\mathrm{MG}$, while strong and negative $(\mathrm{r}=-0.66)$ in the $\mathrm{CG}$ (Figure 9).
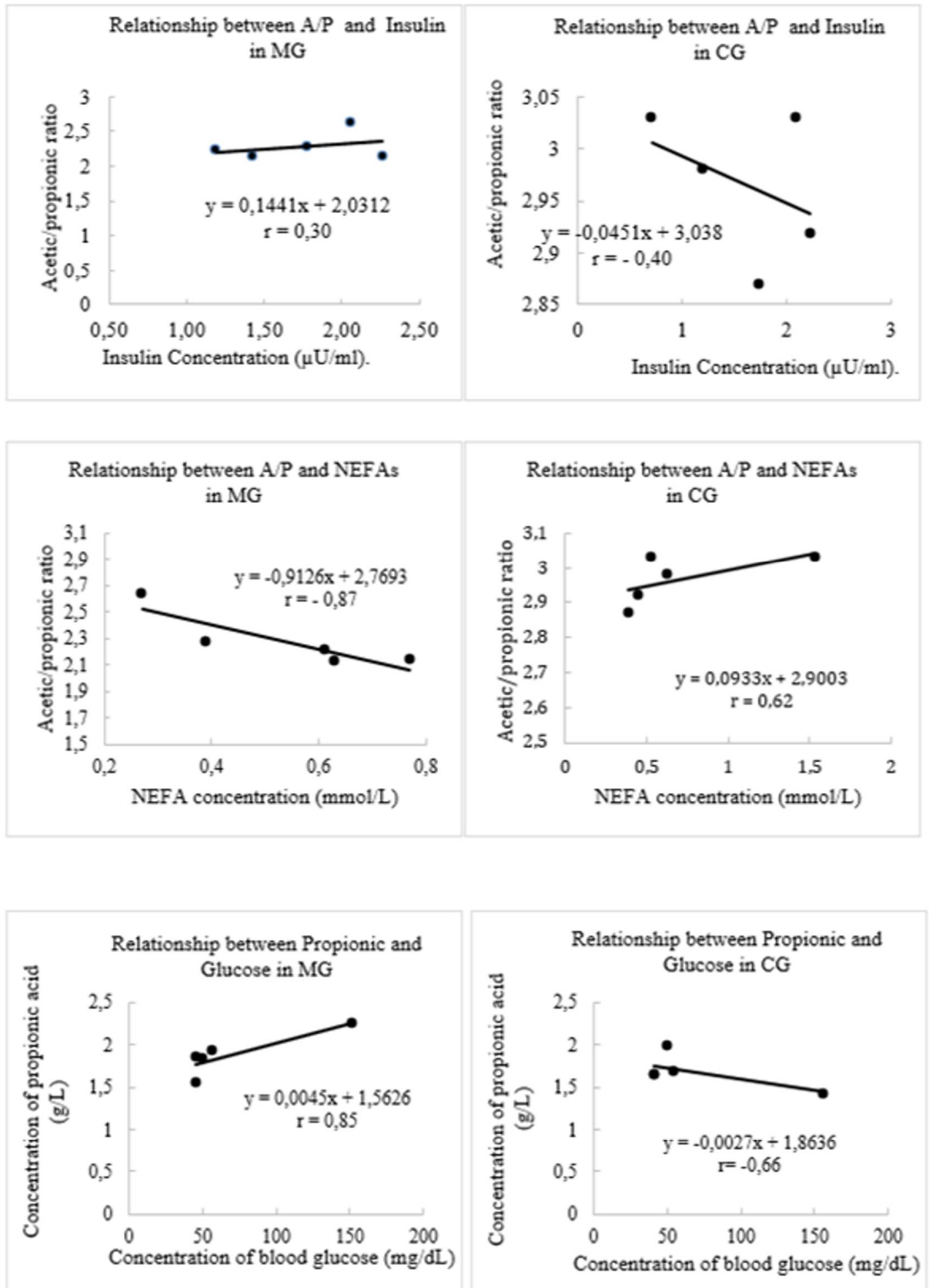

Figure 9. Graphical representation of the correlation coefficients of biochemical and hormonal (Glucose, NEFA, and Insulin) and ruminal indicators (propionic/acetic acid ratio) in the two groups, MG and CG. 


\section{Conclusion}

In this work, the efficiency of monensin sodium in improving the metabolic status and benefiting the energy parameters of dairy goats during peripartum has been observed. This improvement can be evidenced by the decrease in the acetate propionate ratio, reduction in NEFAs values, and higher insulin rate at calving in animals receiving the supplemented diet. Thus, the use of monensin in this species appears to be an interesting tool to prevent metabolic diseases and increase productivity, thereby generating benefits and subsidies for dairy goat farming.

\section{Acknowledgements}

To the Science and Technology Supporting Foundation of the State of Pernambuco (FACEPE) for financial support (Call APQ/FACEPE - No 20/2014 process No 0282-5.05/15), to CAPES for granting the scholarship, and to the Polytechnic School of Pernambuco State (UPE) for carrying out the gas chromatography.

\section{References}

1. Soares GSL, Souto RJC, Cajueiro JFP, Afonso JAB, Rego RO, Macêdo ATM, Soares PC,. Mendonça CL. Adaptive changes in blood biochemical profile of dairy goats during the period of transition. Revue Méd. Vét., 2018;169(1-3): 65-75.

2. Bergen WJ, Bates DB. Ionophores: their effect on production efficiency and mode of action. J. of Anim. Sci. $1984 ; 58: 1465-1483$.

3. Schelling GT. Monensin: mode of action in the rumen. J. Anim. Sci. 1984;58:1518-1527.

4. Duffield TF, Rabiee AR, Lean IJ. A meta-analysis of the impact of monensin in lactating dairy cattle. Part 1. Metabolic effects. J. Dairy Sci. 2008;91:1334-1346.

5. Lima EHF, Mendonça CL, de Paula Cajueiro JF, Carvalho CCD, Soares PC, Afonso JAB, et al. Efeito da monensina sódica sobre o perfil metabólico de ovelhas antes e após o parto. Ciência Animal Brasileira. 2016;17(1):105-118.

6. Austin AR, Wilde RM. The effect of sodium monensin on pregnant ewes. Br. Vet. J. 1985;141:628-634.

7. Vieira LC, Lobo RNB, Barros NN, Portela CHP, Simplício AA. Monensina sódica no controle da eimeriose em caprinos leiteiros. Cie. Anim. 2005;15(1):25-31.

8. Simplício AA, Castelo TS, Silva AR, Mota-Filho AC, Costa LLM. Parâmetros reprodutivos de fêmeas caprinas jovens suplementadas com sal mineral adicionado ou não com ionóforos. Acta Vet. Brasilica. 2011;5(3):259-263.

9. Miranda Neto EG, Silva STG, Mendonça CL, Drummond ARF, Afonso JAB. Aspectos clínicos e a bioquímica ruminal de caprinos submetidos à acidose láctica experimental e suplementados ou não com monensina sódica. Pesq. Vet. Bras. 2011;31(5):416-424.

10. Sadjadian R, Seifi HA, Mohri M, Naserian AA, Farzaneh N. Effects of Monensin on Metabolism and Production in Dairy Saanen Goats in Periparturient Period. Asian-Aust. J. Anim. Sci. 2013;26:82-89.

11. Carlsson J. Simplified gas chromatographic procedure for identification of bacterial metabolic products. 
Appl. Microbiol. 1973;25(2):287- 289.

12. Vieira ACS, Afonso JAB, Mendonça CL. Características do fluído ruminal de ovinos Santa Inês criados extensivamente em Pernambuco. Pesq. Vet. Bras. 2007;27(3):110-114.

13. Brown DL, Hogue DE. Effects of feeding monensin sodium to lactating goats: milk composition and ruminal volatile fatty acids. Journal of Dairy Science. 1985;68:1141-1147.

14. Mousa HM. Ruminal and blood characteristics of nubian goats dosed with the growm promoter monensin. Acta Vet. Brno. 1994;63:3-17.

15. Aderinboye RY, Onwuka CFI, Arigbede OM, Oduguwa OO, Aina ABJ. Effect of dietary monensin inclusion on performance, nutrient utilisation, rumen volatile fatty acid concentration and blood status of West African dwarf bucks fed with basal diets of forages. Tropical animal health and production. 2012;44(5):10791087.

16. Markantonatos X, Aharoni Y, Richardson LF, Varga GA. Effects of monensin on volatile fatty acid metabolism in periparturient dairy cows using compartmental analysis. Animal feed science and technology. 2009;153(1):11-27.

17. Van Maanan RW, Herbein JH, McGilliard AD, Young JW. Effects of monensin in in vivo rumen propionate production and blood ketones in cattle. J. Nutr. 1978;108:1002-1007.

18. Manat TD, Chaudhary SS, Singh VK, Patel SB, Puri G. Hematobiochemical profile in Surti goats during post-partum period. Veterinary world. 2016;9(1):19.

19. Ríos C, Marín MP, Catafaul M, Wittwer F. Concentraciones sanguíneas de ß-hidroxibutirato, NEFA, colesterol y urea en cabras lecheras de tres rebaños con sistemas intensivos de producción y su relación con el balance nutricional. Archivos Medicina Veterinaria. 2006;38(1):19-23.

20. Taghipoor B, Seifi H, Mohri M, Farzaneh N, Naserian AA. Effect of prepartum administration of monensin on metabolism of pregnant ewes. Livest. Sci. 2011;135:231-237.

21. Richardson LF, Raun AP, Potter EL, Cooley CO, Rathmacher RP. Effect of monensin on rumen fermentation "in vitro" and "in vivo". J. Anim. Sci. 1976;43(3):657-664.

22. Sadjadian R, Seifi HA, Mohri M, Naserian AA, Farzaneh N. Variations of energy biochemical metabolites in periparturient dairy Saanen goats. Comparative Clinical Pathology. 2013;22(3):449-456.

23. Leblanc S. Monitoring metabolic health of dairy cattle in the transition period. J. Repro. And Developm. 2010; 56(suppl):S29- S35.

24. Filipovic N, Stojevic Z, Masek T, Mikulec Z, Prvanovic N. Relationship between fructosamine with serum protein, albumin and glucose concentrations in dairy ewes. Small Rumin. Res. 2011;96:46-48.

25. Marca MC, Loste A, Ramos JJ. Effect of acute hyperglycaemia on the serum fructosamine and blood glycated haemoglobin concentrations in canine samples. Vet. Res. Commun. 2000;24:11-16.

26. Armbruster DA. Fructosamine: structure, analysis, and clinical usefulness. Clinical Chemistry. $1987 ; 33: 2153-2163$.

27. Barbosa LP, Rodrigues MT, Guimarães JD, Maffili VV, Amorim LS, Garcez Neto AF. Condição corporal ao parto e perfil metabólico de cabras Alpinas no início da lactação. Revista Brasileira de Zootecnia. 2009;38(10):2007-2014.

28. Pysera B, Opałka A. The effect of gestation and lactation of dairy cows on lipid and lipoprotein patterns and composition in serum during winter and summer feeding. Journal of Animal and Feed Sciences. 2000;9(3):411-424. 
29. Duffield TF, LeBlanc S, Bagg R, Leslie K, Ten Hag J, Dick P. Effect of a monensin controlled release capsule on metabolic parameters in transition dairy cows. J. Dairy Sci. 2003;86:1171-1176.

30. Mundim AV, Costa AS, Mundim SAP, Guimarães EC, Espindola FS. Influência da ordem e estádios da lactação no perfil bioquímico sangüíneo de cabras da raça Saanen. Arq. Bras. Med. Vet. Zootec. 2007;59(2):306-312.

31. Marcos, E.; Mazur, A.; Cardot, P, Rayssiguier, Y. The effect of pregnancy and lactation on serum lipid and apolipoprotein B and A-I levels in dairy cows. J. Anim. Physiol. Anim. Nutr. 1990;64:133-138.

32. Khan JR, Ludri RS. Changes in blood glucose, plasma non- esterified fatty acids and insulin in pregnant and non-pregnant goats. Tropical Animal Health and Production. 2002;34(1):81-90.

33. Carvalho CCD. Indicadores preditivos para o diagnóstico e controle da toxemia da prenhez em ovelhas. Tese (Doutorado). Universidade Federal Rural de Pernambuco, Recife, 2013. 138-139 p.

34. Araújo ASC, Nikolaus JP, Morgado AA, Monteiro BM, Rodrigues AML, Vechiato TAF, et al. Perfil energético e hormonal de ovelhas Santa Inês do terço médio da gestação ao pós-parto. Pesquisa Veterinária Brasileira. 2014;34(12):1251-1257.

35. Basset JM. Endocrine factors in the control of nutrient utilization: ruminants. Nuffield institute for Medical Research, University of Oxford. Proc. Nutr. Soc. 1978;37:273 